\title{
THE EMBLEMATIC EXEMPLUM IN AGUSTÍN MORETO Y CABAÑA AND OTHER GOLDEN AGE PLAYWRIGHTS
}

\author{
EL EXEMPLUM EMBLEMÁTICO EN AGUSTÍN MORETO Y CABAÑA \\ Y OTROS DRAMATURGOS AURISECULARES
}

John Cull

College of the Holy Cross, Worcester

\begin{abstract}
Taking as a point of departure Juan de Horozco's definition: «las emblemas se pueden hazer con figuras solas, como es más ordinario o con figuras y letras que siruan de mote, y esto es, porque la emblema quanto más guardare las propiedades de la empresa tanto será mejor según yo entiendo y juzgara qualquiera" (f. 64v), this study analyzes the presence and function of dramatic emblems in the plays of Agustín Moreto y Cabaña and other Spanish Golden Age Dramatists. It postulates that the poetic images, derived in many instances from emblem books, function as exempla in order to comment on the dramatic situation. The dramatic emblems are divided into two main groups: «marked emblems and «unmarked emblems».
\end{abstract}

KEYWORDS: Agustín de Moreto, argumentum emblematicum, dramatic emblems, exempla.

RESUMEN: Partiendo de la definición de Juan de Horozco de que «las emblemas se pueden hazer con figuras solas, como es más ordinario o con figuras y letras que siruan de mote, y esto es, porque la emblema quanto más guardare las propiedades de la empresa tanto será mejor según yo entiendo y juzgara qualquiera» (f. 64v), este estudio pretende analizar la presencia y función de emblemas dramáticos en las comedias de Agustín Moreto y Cabaña y otros dramaturgos del Siglo de Oro. Se postula que las imágenes poéticas derivadas de libros de emblemas funcionan como exempla para comentar la situación dramática. Los emblemas dramáticos se dividen en dos grupos generales, los «emblemas marcados» y los «emblemas sin marcar».

PALABRAS CLAVES: Agustín de Moreto, argumentum emblematicum, emblemas dramáticos, exempla. 
Although much work remains to be done, the full extent of the influence of emblematics on Spanish Golden Age drama, in all its diverse manifestations, is slowly coming into focus. ${ }^{1}$ From the dramatic pageantry of public festivals, where large numbers of hieroglyphs were accessible to the gaze of all members of society, to solemn funeral exequies, with their moralizing emblems on display for public edification, Spanish cultural artifacts of the early modern period took full advantage of the moral-didactic and entertainment possibilities offered by emblematic representation. It is little wonder that Spanish dramatists availed themselves of the prevailing culture of emblematics to enrich their dramatic productions whenever possible. I would like to focus here on strategies of emblematic exemplarity and persuasion in Agustín Moreto and a number of lesser known Spanish Golden Age dramatists in order to give a hint at how wide-spread this phenomenon actually was.

Among the different strategies identified by Peter M. Daly for emblematic influence in drama, perhaps the most appropriate to the popular theater of the Spanish Golden Age is what he terms (following Schöne), the «argumentum emblematicum». This consists of the evocation by a character in a play of an image derived from an emblem book with its attendant meaning in support of an argument developed to persuade the interlocutor(s). The function of this mode of emblematic persuasion can be defined: "as a foundation for relating the immediate situation to that which is typical and normative, for orienting the particular to the basic for raising the individual and the isolated to the general and eternally valid» (Schöne, cited in Daly, 1979: 161).

In early modern Spain the term «emblem» did not necessarily imply the tripartite structure we currently associate with it. The lengthy theoretical treatise that prefaces the first book of Juan de Horozco's Emblemas morales (Segovia, 1589) dedicates chapter 18 to the differences between emblems and imprese. The most important distinction, for our purposes, is that the emblem does not require the combination of word and image, although it is allowed: «las emblemas se pueden hazer con figuras solas, como es más ordinario o con figuras y letras que siruan de mote, y esto es, porque la emblema quanto más guardare las propiedades de la empresa tanto será mejor según yo entiendo y juzgara qualquiera" (f. $64 \mathrm{v})$. What is more, the emblem is made up of «figuras que significan, y siendo como personas mudas hablan por señas» (f. 64v). A visually oriented poetic image can thus stand alone as a dramatic emblem, without a motto and perhaps without explanatory commentary. But in order to be truly emblematic, the image in question must be didactic and broadly applicable: «la emblema ha de ser para auiso general como regla que pueda conuenir a todos [...] que enseñe algo bueno en negocio de costumbres" (f. 66r). Horozco adds that emblems were invented "para enseñar verdades y desengañar" (f. 66r). As such, dramatic images that stimulate the visual imagination and are moral-didactic in intent are exempla that have the potential to be emblematic, and many such images in fact derive from emblem books.

I exclude from this study those poetic images that constituted commonplaces repeated ad infinitum in Spanish Golden Age literature, but which nevertheless could be argued to

1. See the appendix for the most important studies published to date on the influence of emblematics on Calderón de la Barca, Lope de Vega, Tirso de Molina and other Spanish Golden Age playwrights. 
be emblematic as well due to their frequent appearance in emblems books. One such motif is the embrace of the vine and elm, or vine and wall, ${ }^{2}$ a convention so frequent that Felip Godínez practically apologizes for repeating it in Aún de noche alumbra el sol:

Imaginad, si no pierde

quizás por muy repetida

la comparación, asida

a un olmo una yedra verde,

que en recíproca amistad

se unen los dos de tal modo,

que en las partes de este todo,

no hay ya unión, sino unidad. (III, vv. 2155-2162)

Other poetic commonplaces of this type include: the salamander that thrives in the flames, ${ }^{3}$ the chameleon that sustains itself on air alone, ${ }^{4}$ the precocious flowering of the almond tree, ${ }^{5}$ the ungrateful viper or asp that bites whoever warms it at his breast, ${ }^{6}$ the candle that burns brightest just before it consumes itself completely, ${ }^{7}$ the pelican that shreds her breast in order to nourish her young with her blood, ${ }^{8}$ Occasion, who must be seized by her forelock before she passes by, ${ }^{9}$ the rémora (suckerfish) capable of stopping a huge ship dead in the water, ${ }^{10}$ the mighty oak tree that breaks in a strong wind while the humble cane

2. The examples that follow in these notes derive exclusively from the plays consulted for this study. Many more could be adduced for other Golden Age playwrights not represented here: Moreto, En el mayor imposible nadie pierda la esperanza, Act 3, p. 636; Moreto, El más ilustre francés, san Bernardo, Act 1, f. 138v and Act 2, f. 147v; Moreto, La discreta venganza, Act 2, p. 381; Moreto, Lo que merece un soldado, Act 1, p. 10 (a play also attributed to Felipe Godínez with the title Cautelas son amistades); Moreto, El valiente justiciero, Act 2, p. 339; Moreto, Los jueces de Castilla Act 2, p. 475; Moreto, El defensor de su agravio, Act 1, p. 496; Villaizán y Garcés, A gran daño, gran remedio, Act 1, p. 228; Villaizán y Garcés, Transformaciones de amor, Act 1, f. 5v; Tárrega, La fundación de la orden de Nuestra Señora de la Merced por el Rey Don Jaime, Act 2, unpaginated; Claramonte, Santa Teodora (Púsoseme el sol, salióme la luna), Act 1 , vv. 632-34; Claramonte, El valiente negro en Flandes, Act 2, f. 170v; Claramonte, El gran rey de los desiertos, san Onofre, Act 3, p. 29; Matos Fragoso, Los dos prodigios de Roma, Act 2, p. 76; Matos Fragoso, Muchos indicios sin culpa (also attributed to Calderón), Act 2, p. 14; Monroy y Silva, Las violencias del amor, Act 2, unpaginated; Cubillo de Aragón, El mejor rey del mundo, y templo de Salomón, Act 3, f. 13r; Cubillo de Aragón, El señor de noches buenas, Act 1, p, 6.

3. Moreto, El Eneas de Dios, Act 1, p. 159; Tárrega, La fundación de la orden de Nuestra Señora de la Merced por el Rey Don Jaime, Act 3, unpaginated; Claramonte, De Alcalá a Madrid, Act 3, f. 16v; Matos Fragoso, El fénix de Alemania. vida y muerte de Santa Cristina, Act 2, p. 399 and p. 406; Monroy y Silva, El robo de Elena, Act 3, pp. 29-30.

4. Moreto, El secreto entre dos amigos, Act 2, p. 571; Tárrega, Las suertes trocadas, y torneo venturoso, Act 3, unpaginated; Tárrega, La fundación de la orden de Nuestra Señora de la Merced por el Rey Don Jaime, Act 3, unpaginated; Matos Fragoso, El yerrro del entendido, Act 3, p. 107; Monroy y Silva, San Bartolomé en Armenia, Act 3, unpaginated.

5. Moreto, En el mayor imposible nadie pierda la esperanza, Act 1, p. 628; Moreto, Empezar a ser amigos, Act 1, p. 351; Moreto, Trampa adelante, Act 2, p. 154; Moreto, Industrias contra finezas, Act 1, p. 269; Tárrega, Las suertes trocadas, y torneo venturoso, Act 2, unpaginated; Matos Fragoso, El traidor contra su sangre, Act 1, p. 6.

6. Moreto, En el mayor imposible nadie pierda la esperanza, Act 2, p. 628; Moreto, La fingida Arcadia, Act 1, p. 3; Villaizán y Garcés, A gran daño, gran remedio, Act 1, p. 228; Matos Fragoso, Riesgos, y alivios de un manto, Act 2, pp. 18-19. 7. Moreto, En el mayor imposible nadie pierda la esperanza, Act 2, p. 632.

8. Moreto, El azote de su patria, y renegado Abdenaga, Act 1, p. 428; Tárrega, Las suertes trocadas, y torneo venturoso, Act 2, unpaginated; Tárrega, La sangre leal de los montañeses de Navarra, Act 3, unpaginated; Matos Fragoso, Los dos prodigios de Roma, Act 1, p. 51; Cubillo de Aragón, El bandolero de Flandes, Act 3, p. 31.

9. Moreto, El azote de su patria, y renegado Abdenaga, Act 2, p. 437; Moreto, El rosario perseguido, Act 1, p. 11; Moreto, San Franco de Sena, Act 3, p. 140; Moreto, Lo que puede la aprehensión, Act 3, p. 182; Solís, Amparar al enemigo, Act 1, p. 356; Solís, Eurídice y Orfeo, Act 3, p. 102; Tárrega, Las suertes trocadas, y torneo venturoso, Act 2, unpaginated; Claramonte, Santa Teodora (Púsoseme el sol, salióme la luna), Act 1, vv. 529-31; Monroy y Silva, El más valiente andaluz, Antón Bravo, Act 2, p. 17; Cubillo de Aragón, El señor de noches buenas, Act 1, p, 1.

10. Moreto, El marqués del Cigarral (also attributed to Alonso del Castillo Solórzano), Act 1, p. 1; Tárrega, El prado de Valencia, Act 1, unpaginated; Matos Fragoso, Ver y creer (continuation of Vélez de Guevara's Reinar después de

IMAGO, NÚM. 9, 2017, I51-170 
merely bends, ${ }^{11}$ the peacock whose vanity is quashed by looking down at his ugly feet, ${ }^{12}$ the vigilance of the crane, ${ }^{13}$ the ungrateful viperlings that kill their mother during childbirth, ${ }^{14}$ the ambition of the winged ant, ${ }^{15}$ the butterfly or moth attracted to the flame, ${ }^{16}$ the eagle that tests the legitimacy of its offspring by having them stare directly into the sun, ${ }^{17}$ etc.

\section{MARKED EMBLEMS}

By «marked» emblems, I mean those instances where the dramatist draws attention to the fact that the visual image about to be introduced has a parallel in a non-literary tradition that is in many instances an emblem book, although we cannot ignore fables, natural histories and other similar works as possible sources. By drawing the spectator's attention to a possibly emblematic source, the dramatist is by extension asking the receptor to apply the emblematic meaning to the dramatic situation at hand. The easiest marked emblems to locate are those instances when a dramatic character explicitly refers to a particular image or situation as an emblema, empresa or jeroglífico. Agustín Moreto y Cabaña offers an example of this kind of emblem in Los siete durmientes ( $y$ más dichosos hermanos), when Penélope describes for the audience what she sees at her window ledge, specifically identifying it as an emblem:

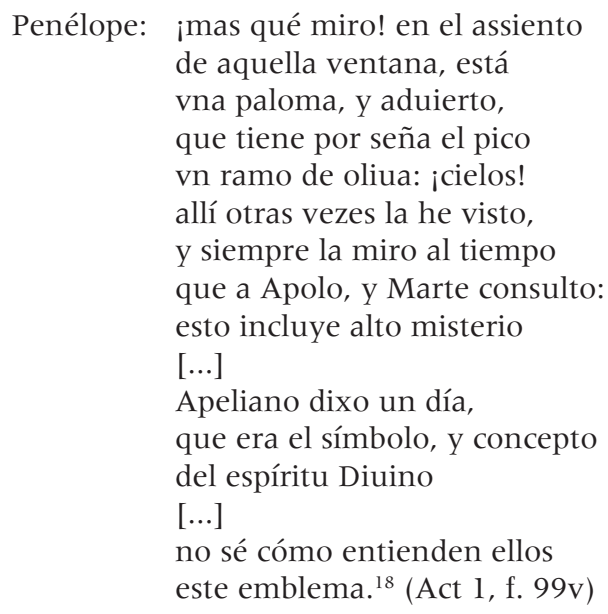

morir), Act 2, p. 66; Cubillo de Aragón, Los desagravios de Cristo, Act 3, p. 250; Cubillo de Aragón, Segunda parte del conde de Saldaña, y hechos de Bernardo del Carpio, Act 2, p. 60 (mispaginated as 58).

11. Moreto, La misma conciencia acusa, Act 1, p. 104; Matos Fragoso, Estados mudan costumbres, Act 3, p. 114.

12. Solís, Triunfos de amor, y fortuna, Act 1, p. 7; Cubillo de Aragón, El ejemplo de desdichas, y los casados por fuerza, Act 2, f. 8r.

13. Villaizán y Garcés, Venga lo que viniere, Act 1, f. 100v; Matos Fragoso, El genízaro de Hungría, Act 3, p. 25; Cubillo de Aragón, La perfecta casada, Act 2, p. 12.

14. Tárrega, La sangre leal de los montañeses de Navarra, Act 2, unpaginated; Tárrega, La enemiga favorable, f. 317r; Matos Fragoso, Lorenzo me llamo, carbonero de Toledo, Act 1, p. 146; Monroy y Silva, Renegado, rey y mártir, Act 1, unpaginated; Cubillo de Aragón, El amor como ha de ser, Act 3, unpaginated; Cubillo de Aragón, El conde de Saldaña (Primera parte), Act 3, unpaginated.

15. Tárrega, La duquesa constante, Act 1, unpaginated.

16. Matos Fragoso, A su tiempo el desengaño, Act 2, f. $76 \mathrm{v}$.

17. Matos Fragoso, Muchos indicios sin culpa (also attributed to Calderón), Act 2, p. 14; Matos Fragoso, Amor, lealtad y ventura, Act 3, unpaginated; Cubillo de Aragón, La corona del agravio, Act 2, p. 13.

18. Play titles are cited with their orthography modernized. Textual citations respect the original orthography, but 
The intent of the emblem is to persuade Pénelope that she should convert to Christianity. Juan Francisco de Villava includes an impresa with the same image and meaning in his Empresas espirituales y morales (Baeza, 1613). The pictura depicts a dove in flight with an olive branch in its beak, and the motto reads simply Post nubila (After the rain). It is in the verse subscriptio and prose commentary where Villava identifies the image as a symbol of Christ bringing peace and reconciliation to the world (Primera parte, Emp. 10, De Christo pacífico, f. 33r).

Emblematic evocation is not always intended to be exemplary in Spanish Golden Age drama. Moreto makes a humorous reference to emblematic depiction in La fortuna merecida (Merecer para alcanzar), when the gracioso Viznaga describes for the queen his visit to the prison cell of the Duke. His verbal depiction portrays the Duke as though he has mottoes written on phylacteries issuing from his mouth:

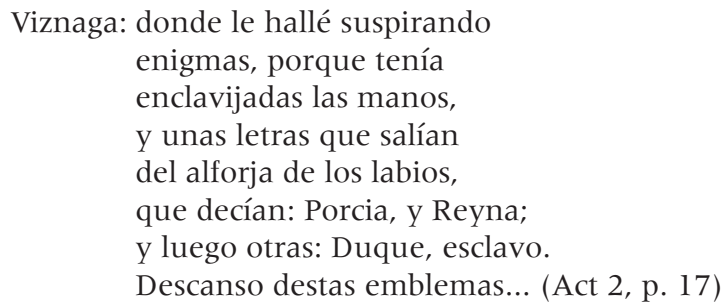

There is clearly no moral-didactic purpose to this description by Viznaga, but it appeals in a playful way to a phenomenon that clearly would have been familiar to the audience. Since the gracioso often has the function of satirizing stale conventions, we can speculate that Viznaga's humorous allusions to emblems might be an indication that Moreto considered them to be an ordinary, and perhaps over-used convention in Spanish drama by the middle of the seventeenth century.

Another explicit identification of a verbal image with an emblem is found in Andrés de Claramonte's Famosa comedia de Santa Teodora (Púsoseme el sol, salióme la luna). The dramatic text presents several difficulties that I have not been able to resolve, ascribing the alleged «emblem» to Euripides:

Lesbia: Ya puedo

referirte aquella emblema

de Eurípides a Cupido

y Venus, estáme atenta,

porque a propósito viene.

Alcina: ¿Qué hay que mujeres no emprendan?

Lesbia: Venus halló una tarde a Amor dormido

en los regazos de sus ninfas flores,

que de la dura ley de sus amores

plantas así se habían redimido.

Y viendo la ocasión que ha pretendido,

quiso vengar rigores con rigores,

y quitándole el Iris de colores,

flechándole gentil, le dejó herido.

modernize accentuation. Many of the plays quoted in this study can be found at the Cervantes Virtual website [http://www.cervantesvirtual.com].

IMAGO, NÚM. 9, 2017, I5I-170 


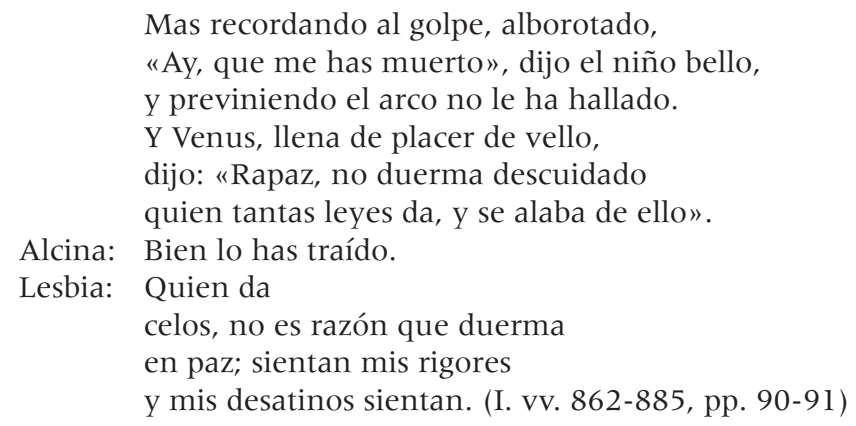

I know of no dramatic text by Euripides that narrates a scene in which Aphrodite shoots a sleeping Eros with his own bow, nor have I located a concrete emblem on this theme in Vaenius or any other emblem book consulted. ${ }^{19}$ In any event, the application of this apparent non-emblem is clear: Lesbia, like Venus, wants to get revenge on Teodora, who has inflicted a wound by taking Natalio away from her. What is most interesting about this "emblematic» and highly visual anecdote is the narrator's awareness of how it applies, in the manner of an exemplum, to the dramatic situation at hand ("porque a propósito viene»). ${ }^{20}$

A second strategy for marking possibly emblematic images as a hint to the audience is the use of certain formulas that invite visualization. Perhaps the most frequent formula of this type in Golden Age drama is the rhetorical question "¿Has visto?», often followed by the term "así» when the image is explicitly applied to the situation at hand. Consider this example from El delincuente sin culpa, y bastardo de Aragón by Juan de Matos Fragoso:

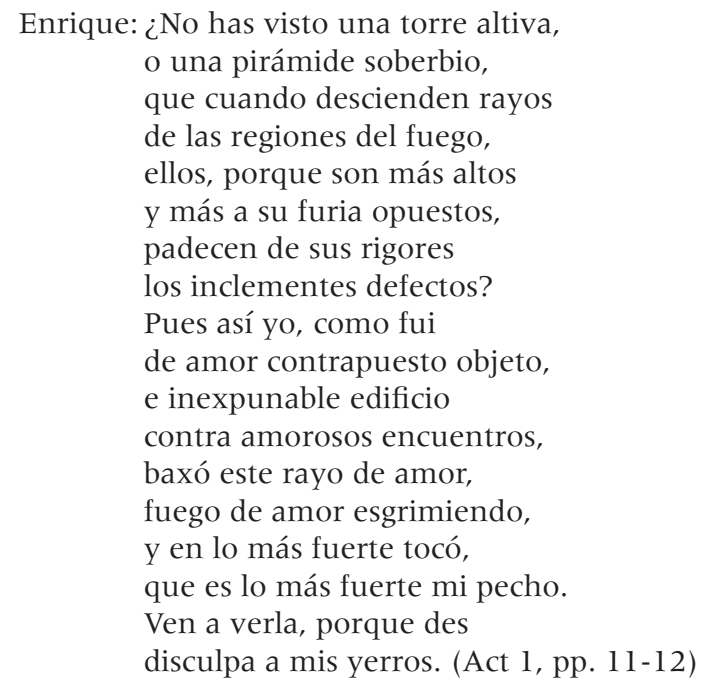

19. Rodríguez López-Vázquez offers no information to solve these enigmas in his edition of the play. This could of

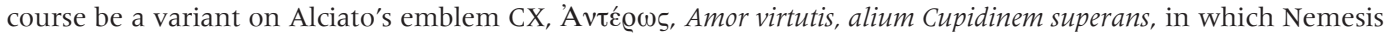
tortures Cupid with his own arrows.

20. Another example of explicit mention of the word "emblema" in the plays consulted for this study is Matilde's description of la Florida in También ay piedad con zelos by Garcia Aznar Vélez: «es Emblema floreciente, /de sus Monarcas invictos, / la Real purpúrea Diadema» (Act 1, p. 319). 
Enrique evokes here the beauty of Doña Inés de Acuña, the king's bride to be with whom he has fallen in love at first sight. A possible source for this image is Juan de Borja's impresa with the motto Celsa graviore casu decidunt (Tall Things Suffer Greater Falls). The pictorial motifs feature a tower being toppled by bolts of lightning. Borja's commentary makes it clear that Enrique is not only humbled by love's power to vanquish his haughtiness, but he is also aware of the risk he is taking with his lofty ambition to win the hand of the king's intended bride: "Lo más seguro, y mejor sería, contentarse cada uno con el estado en que nació [...] y con esto se viviría con más quietud, y contento» (Primera parte, 190-91). With the evocation of the emblematic image, Enrique is, in a sense, cautioning himself to be aware of the consequences of his action. ${ }^{21}$

Another example of the formula "¿Has visto?» can be found in Andrés de Claramonte's Famosa comedia de Santa Teodora (Púsoseme el sol, salióme la luna), when Natalio somewhat cruelly taunts his former lover Lesbia with the superior beauty of the woman he now intends to marry, Teodora:

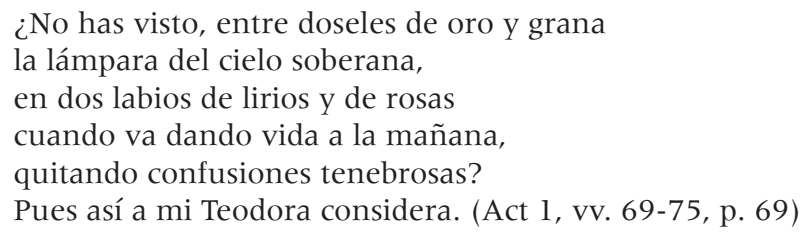

The morning sun chasing away the darkness of the night is the subject of a number of Spanish emblems, such as Borja's Nitor in adversum (Primera parte, 20-21) or Covarrubias Horozco's Post nubila clarior (Lib. 2, Emb. 6, f. 120r), but the image evoked is too generic to identify it with any particular emblem.

Moreto's El desdén con el desdén varies the formula slightly by changing the verb tense of ver. Here it is the gracioso Polilla who develops an extended metaphor that is a recurring leitmotif in the text in which he encourages his master Carlos to remain steadfast in his pretended disdain of Diana, and in so doing he will eventually wear down her resistance and she will fall in love with him.

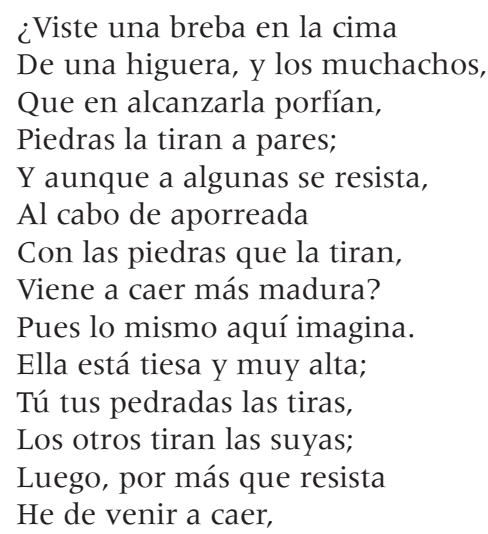

21. A similar image is described in El yerro del entendido by Juan de Matos Fragoso, when Laura warns: "y no os fiéis de la dicha, / que os tiene en puesto tan alto, /pues contra el más poderoso / Baja con más furia el rayo (Act 2, p. 88).

IMAGO, NÚM. 9, 2017, I5 |- 170 
De una y otra a la porfía,

Más madura que una breba.

Mas cuidado a la caída,

Que el cogerla es lo que importa;

Que ella caerá, como hay viñas. (Act 1, p. 3)

In the emblematic tradition we think immediately of Alciato's emblem In fecunditatem sibi damnosam (On fertility that condemns itself), that depicts boys throwing stones at a walnut tree and beating it with sticks to get its nuts. The application, however, is different in the emblem, where the intent is to condemn those fathers who engender evil offspring. The moral voiced by Polilla of perseverance is more appropriate to Alciato's Obdurandum adversus urgentia (One must resist that which weighs one down), where a boy hangs persistently from the branches of a palm tree in an attempt to reach its dates, an effort that promises to be rewarded in due time. ${ }^{22}$

Very similar to the "¿Has visto?» formula is the syllogistic (in the general sense of a mediated inference or deduction) combination: "Como ... así», where the first part ("como») is followed by the image in question and the second part "asín is the application to the case at hand. In the example that follows from Cubillo de Aragón's Añasco, el de Talavera, the order of the two terms of the formula is reversed, probably for the purpose of the rhyme scheme:

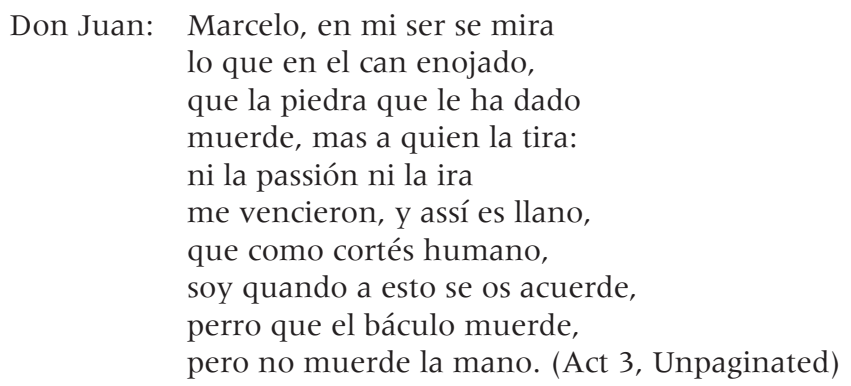

Juan, in this scene, does not want old Marcelo to find out the identity of the women that the former has hidden away. When challenged by Marcelo, Juan breaks the old man's cane instead of wounding him with his sword. He is thus like Alciato's dog in emblem 174 with the motto Alius peccat, alius plectitur (Pagan justos por pecadores) that bites the stone thrown at him instead of the hand of the one who threw it. The same emblem can be found in unmarked fashion in Los bandos de Ravena y fundación de la Camándula by Juan de Matos Fragoso:

quando un aviso me dieron de que irritados sus hijos, y de la cólera ciegos, dar intentaban la muerte a Violante como a reo, por haver sido el motivo de aquel infeliz sucesso,

22. This emblem is invoked in El primer condenado by Felipe Godínez, when Adam comments on his son Abel's recovery from a fainting spell: "y eres la palma primera / que con el peso oprimida, / vitoriosa se descuella" (Act 1 , unpaginated). 


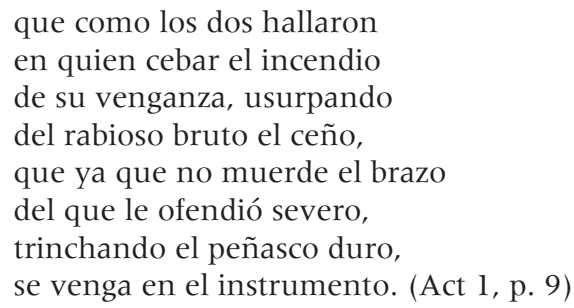

Carlos here is referring to the fury of Violante's brothers. ${ }^{23}$

A variant of the "Como asín formula is at play in Ofender con las finezas by Jerónimo de Villaizán y Garcés. Here, Blanca has just informed the sexually aggressive Conde de Barcelona that she will not marry him because of their difference in social class. She vows to take whatever action necessary to protect her purity, comparing herself both to the rose and the ermine:

No señor, porque si tiene la rosa beldad que atrae, también para su defensa tiene espinas que la guarden. Que aún la irracional belleza tiene priuilegios tales, que se cría en la defensa, desde que al peligro nace. Bien assí como el armiño, cándido copo del valle, que por no ofender la nieue del pellico, elige antes morir, que viuir, y ver, que su honestidad se manche, su cándida piel se injurie, y su pureza se vltraje. (Act 1, p. 181)

The rose that protects its purity with thorns appears in emblem books, but it is a poetic commonplace. The image of the ermine, however, that refuses to soil the whiteness of its fur by walking through mud, in combination with the meaning of guarding chastity, is much more likely to derive from an emblematic tradition. An early example of this can be found in Giovio's Diálogo de las empresas militares, $y$ amorosas (1562).24

The final form of marked emblems that we will consider are those cases where the dramatist invokes the ut pictura poesis topos by referring to the manner in which a certain concept is "painted", especially by the ancients. Antonio Coello y Ochoa's El celoso extremeño offers a good example when Juan describes the artistic rendition of fame:

23. Another unmarked emblem of the dog biting the stone instead of the hand that threw it appears in Moreto's El más ilustre francés, san Bernardo, when Demonio observes: «Rabioso can / intento ser, que ocurre / a la vengança en la piedra, / ya que en el dueño no pude». (Act 1, f. 138v)

24. See Cull 2002 for other examples of the ermine emblem. There is a modern edition of Giovio edited by Jesús Gómez (Madrid: Polifemo, 2012).

IMAGO, NÚM. 9, 2017, 151-170 
Quando no añade la fama, que el pintarla todo el cuerpo lleno de ojos, y de lenguas, no fue solo, según pienso, darnos a entender que ve, sino también fue dezirnos en su enigma, que al respeto de sus lenguas, y sus ojos ve en vno muchos objetos [...] auara entonces la fama, para dezirlos, y verlos [defectos] todas sus lenguas son mudas, todos sus ojos son ciegos. (Act 1, f. $134 \mathrm{r}-\mathrm{v}$ )

Coello's depiction may have been more influenced by Virgil's description of Fama (in Aeneid IV line 180 and following), than by the emblem tradition, given the reference to her gown being covered by multiple tongues and eyes. Spanish emblems of Fame, such as Soto's Nihil tam volucre quam maledictum (Nothing is as swift as an abusive word), adorn the gown with eyes and wings, but not tongues.

A second example of this form of marking a dramatic emblem is found in Cristóbal de Monroy y Silva's La alameda de Sevilla y recato en el amor. Here Leonor describes how antiquity depicted love:

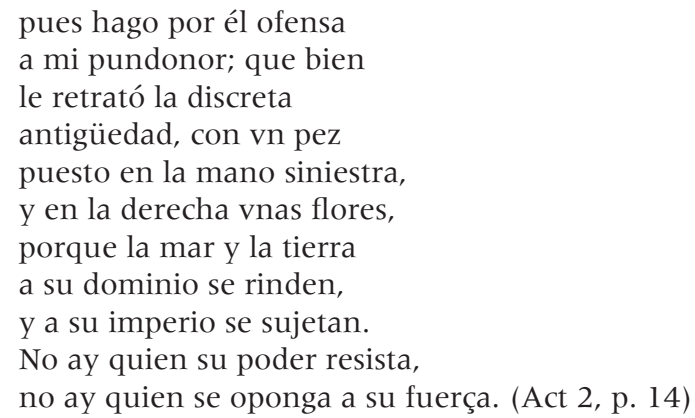

Monroy y Silva likely had in mind Cesare Ripa's Force of Love, that depicts a winged Cupid figure with a Dolphin in its right hand and a Garland of flowers in the left hand (fig. 125).

\section{UNMARKED EMBLEMS.}

Many other dramatic emblems flow naturally from the dramatic dialogue, with no attention-grabbing device to alert the spectator that an emblematic motif will follow. In these instances the spectator must make the leap of imagination to first recognize a possibly emblematic antecedent, and then apply the meaning to the situation at hand. For example, in Cristóbal de Monroy y Silva's Lo que puede el desengaño y memoria de la muerte, the evil bandolero Lamberto orders Julia to leave the room with this enigmatic explanation: 


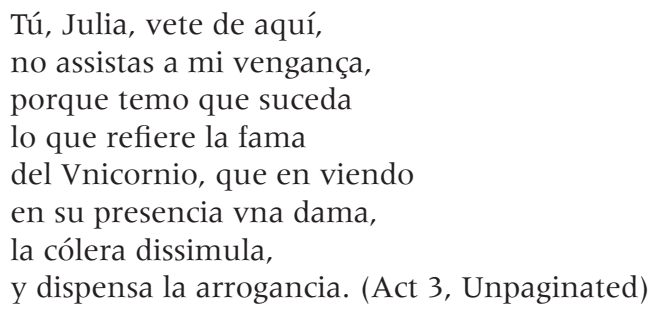

In addition to other possible sources for this bit of lore, ${ }^{25}$ Monroy y Silva may be alluding here to an emblem found in Joachim Camerarius, whose Symbola et emblemata (Centuria, I: 1590, II: 1595, III :1596, IV: 1604) was widely disseminated. The second volume, dedicated to four-legged animals, includes several emblems on the unicorn. Number 13, with the motto Hoc virtutis amor (This Power of Love), depicts a unicorn resting his head in the lap of a damsel, presumably a virgin, seated at the foot of a tree. Several other smaller land animals, including snakes, and possibly a squirrel, flee from this normally savage beast, conquered by chaste love (II.XIII, pp. 26-27). The message is clear: Lamberto fears that being in the presence of Julia might cause his uncontrollable lust to dissipate, something he does not want in this dissolute phase of his life.

A surprisingly common unmarked emblem is Spanish Golden Age drama is based on the musical concept of sympathetic resonance, or vibration, in which an untouched string instrument sounds when a nearby instrument is played that has a harmonic likeness. When applied in an amorous context, it is an apt metaphor for the souls of two lovers who are perfectly matched and attuned to one another. A well-developed example occurs in Eurídice y Orfeo by Antonio de Solís, when Eurídice explains to Orfeo why they both shared the same dream the previous evening:

También pudo ser, esposo, que como dos instrumentos acordemente templados, suelen hazer vn concierto, aunque la atreuida mano hiera solo el vno dellos, nuestras dos almas assí ha templado el amor nuestro: de suerte, que en dulce vnión las mueue solo vn deseo, aun quando estauan dormidas, tan confomes estuuieron, que apenas hirió mi idea la torpe mano del sueño, quando dentro de la tuya se oyeron los mismos ecos $[\ldots]$ pues se mueuen nuestras almas por vnos mismos afectos, y pudo ser harmonía, lo que juzgamos agüero. (Act l, p. 81)

25. The unicorn prostrate before a seated virgin can be found in Leonardo da Vinci's notebooks, in fifteenth century tapestries, and in other artistic renditions as well. The dramatist's source therefore is not necessarily emblematic. 
I am aware of only one early emblem that deals with this phenomenon, which appeared in 1618 in Silenus Alcibiadis, sive, Proteus, by the Dutch poet and emblematist Jacob Cats ${ }^{26}$. A second example of this emblematic image proceeds from Moreto's El mejor amigo el rey. Here, however, it is not utilized in an amorous context. King Pedro asks his privado Enrique to feign that he has fallen out of favor, in order to test the loyalty and political ambitions of Prince Alejandro:

Que aunque obren con más recato,

Cuando ofendido te crean,

Así cual dos instrumentos

Templados a una cadencia,

Al herir el uno, el otro

Con el mismo acento suena, --

Si tú te muestras templado

$\mathrm{Al}$ tenor de sus cautelas,

Cuando se toque tu labio,

Aunque más recato tengan,

Será preciso que suene

$\mathrm{Al}$ acento de su queja. (Act 1, p. 605)

In other words, if Enrique (as the untouched instrument) maintains his silence in the face of the insults and outrages he will endure in his alleged fall from grace, the truth of the machinations of the Prince and his fellow conspirators (the instrument played) will eventually sound loud and clear. ${ }^{27}$

Another unmarked dramatic emblem in a Moreto play appears to evoke an emblem found in the Emblemas morales of Sebastían de Covarrubias Horozco. In Lo que merece un soldado (also attributed to Felipe Godínez with the title Cautelas son amistades), ${ }^{28}$ the newly elevated Conde Carlos ponders the sudden change in his fortune, and that of the Senescal, stripped of his title by the king in order to reward Carlos:

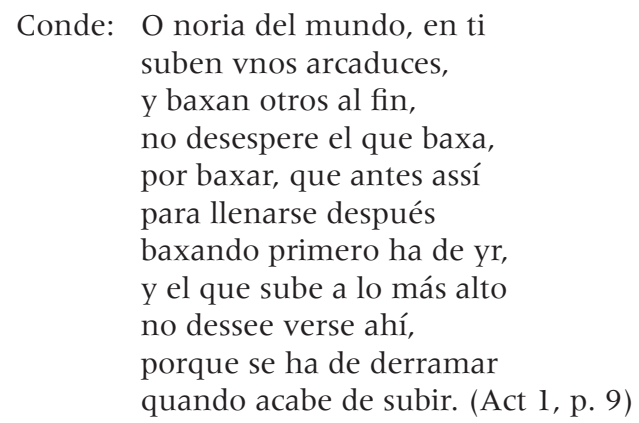

26. A later Spanish emblem of this topic appeared in Lorenzo Ortiz, Memoria, entendimiento y voluntad (1677), f. 103r. For a more detailed description of the Cats emblem and examples from the plays of Alarcón and Cubillo de Aragón, see Cull 2016 and 2017.

27. For other examples of sympathetic vibration, see Tárrega, El cerco de Rodas (Act 2, unpaginated), El prado de Valencia (Act 2, unpaginated) and La enemiga favorable (f. 312v); Matos Fragoso, Los dos prodigios de Roma (Act 3, p. 83) and Moreto, Empezar a ser amigos (Act 2, p. 362)

28. Indeed, Godínez evokes the same emblematic image in several other plays. See, for example, Amán, y Mardoqueo (por otro título, La horca para su dueño), Act 3, unpaginated, and Acertar de tres la una, Act 2, p. 19. 
Covarrubias Horozco's emblem has as its motto practically the same words uttered by Carlos: "Unos suben y otros baxan», while the prose commentary echoes the same disillusionment expressed by the protagonist:

Con Grande propriedad se comparan a los alcaduzes de la noria a los estados desta vida porque unos van subiendo llenos de agua a lo más alto de su rueda, y de allí es fuerça baxar, decargándose, y baxando vacíos. Los que están en gran prosperidad no se desvanezcan, que en vida, o en muerte han de ser despojados de sus riquezas y prosperidades (Cent. 3, Emb. 55)

The unmarked emblems of the dramatists included in this study are fairly numerous, and I list here briefly, with their emblematic parallels, some of the most salient examples. In Moreto's La misma conciencia acusa, Carlos observes that those who rise to a prominent position in the world and allow themselves to become vainglorious and arrogant are destined to fall, just as the mighty oak is toppled by a strong wind, while the humble reed survives and flourishes (p. 104; Borja, Superbis resistit, humilibus dat gratiam, Segunda parte, 432-33). In Antonio Coello y Ochoa's Celos, amor y cordura, Blanca warns her lover don Juan to keep his distance from the monarch, for he represents light when seen from a distance, but can burn if one approaches too close (Act 3, f. 63r; Saavedra Fajardo, Idea de un príncipe, Documento LXXV, Regum calor quomodo suscipiendus). In Bances Candamo's El esclavo en grillos de oro, Cleantes cautions the monarch Camilo against venting his passions, stating that a king must always remain impassive and inscrutable, with a serene countenance that is exempt from alteration, just like the summit of Mount Olympus (Act 3, p. 32; Soto, Solo in Caelo securitas, Emb. 13, f. 26). In Álvaro Cubillo de Aragón's El mejor rey del mundo, y templo de Salomón, King David offers his son Salomon advice on good governance with the analogy of the world as a clock in which the monarch is the principle gear, a clock which will all fall apart if its movement is backward instead of forward (Act 1, ff. 2r-v; Saavedra Fajardo, Empresas políticas, Empresa 57, Uni reddatur and Borja, A supremo dirigatur, Segunda parte, 398-99). In La venganza en el despeño, y tirano de Navarra by Juan de Matos Fragoso, Martín compares the king to the laurel tree, infallible and immune to damage from a lightning strike (Act 3, p. 23; Alciato, Laurus).

Space limitations prevent me from studying in any depth the actual staging of emblems in Spanish Golden Age drama, a phenomenon quite frequent in discovery scenes and in court productions with abundant use of stage machinery and special effects. ${ }^{29}$ I will provide a single example, however, from Juan de Matos Fragoso's El hijo de la piedra, y segundo Pío Quinto, San Félix. The play begins with Félix carrying his invalid father onstage in his arms, as indicated in the stage direction: Sale Félix sacando a su padre como en brazos. The ensuing dialogue makes it clear that this is intended to depict an act of filial piety:

Félix: Padre, en mis brazos venid, y aquí, donde el Sol calienta, estaréis mejor sentado. [...]

Perote: Páguete el cielo, hijo mío, la piedad con que alimentas mi vejez. (Act 1, pp. 1-2)

29. For emblematic discovery scenes in the plays of Tirso de Molina, see Cull 1996.

IMAGO, NÚM. 9, 2017, I51-170 
The emblematic precedent of this scene that combines visual action with moral-didactic words is Alciato's Pietas filiorum in parentes, which shows Aeneas fleeing from Troy in flames with his crippled father Anchises on his back. This same emblem was imitated by Juan de Horozco in his Emblemas morales (Lib. III, Emb. 11, f. 232r).

According to Juan de Zabaleta, "Decir lo que nadie ha imaginado es ser poeta» (p. 54). The appeal to the visual imaginary is a fundamental aspect of Spanish Golden Age drama in a theater normally devoid of decoration. Perhaps we do not give enough credit to the ability of seventeenth century theatergoers to discern, assimilate and apply visually symbolic imagery that the poet paints in the mind's eye of the spectators. Indeed, Zabaleta satirically recommends to poets that they hire painters to render their imagery visually in order to determine the efficacy of the verses: "Llame a un pintor, haga que le copie con un pincel lo que él ha escrito con la pluma y verá lo que ha escrito» (p. 56). Dramatic emblems in the Spanish Golden Age allowed the audience, in the words of Zabaleta, to "see with their ears».

\section{BIBLIOGRAPHY}

Alciato, A. [1549 = 2003]. Los emblemas de Alciato traducidos en Rimas Españolas, 1549, ed. Rafael Zafra, Barcelona, José de Olañeta, Editor and Edicions UIB.

Aznar Vélez, G. [1704]. También hay piedad con celos, in Comedias nuevas, parte quarenta y ocho, escogidas de los mejores ingenios de España, Madrid, Francisco Martinez Abad, pp. 315-62.

Bances Candamo, F. A. DE. [1782]. El esclavo en grillos de oro, Valencia, Imprenta de Joseph y Thomás de Orga.

BoRJA, J. DE. [1581 = 1680]. Empresas morales, Bruselas, Francisco Foppens.

CAmerarius, J. [1590 = 1668]. Symbola et Emblemata: Cent. quatuor. Akad, Dr.- u. Verlag-Anst. CATs, J. [1618]. Silenus Alcibiadis, sive, Proteus: vitae humanae ideam emblemate...,

Middelburgi, Ex officina typographica Iohannis Hellenij.

Claramonte Y corroy, A. DE. [1638]. El valiente negro en Flandes, in Parte treynta vna, de las meiores comedias, que hasta oy han salido, Barcelona, Emprenta de Iayme Romeu, ff. $157 \mathrm{v}-179 \mathrm{r}$.

Claramonte Y Corroy, A. de. [1985]. Púsoseme el sol, salióme la luna, ed. A. Rodríguez LópezVázquez, Kassel, Edition Reichenberger.

Claramonte y corroy, A. de. [S. A.]. El gran rey de los desiertos, San Onofre, Sevilla, Francisco de Leefdael.

Coello Y OchoA, A. [1634]. El celoso extremeño, in Parte veynte y ocho, de comedias de varios autores, Huesca, Pedro Bluson, ff. 134r-151v.

- [1638]. Celos, honor y cordura, in Parte treynta vna, de las meiores comedias, que hasta oy han salido, Barcelona, Emprenta de Iayme Romeu, ff. 49r-69r.

Covarrubias Horozco, S. De. [1610]. Emblemas morales, Madrid, Luis Sánchez.

Cubillo de Aragón, Á. De. [1654]. Los desagravios de Cristo, in El enano de las musas, Madrid, María de Quiñones.

- [1669]. Segunda parte del conde de Saldaña, y hechos de Bernardo del Carpio, in De los mejores el mejor, libro nueuo de comedias varias, nunca impressas, compuestas por los mejores ingenios de España: parte treze ..., Madrid, Mateo Fernandez, pp. 42-72. 
Cubillo de ARAgón, Á. De. [1758]. La perfecta casada, por otro nombre, prudente, sabia y honrada, Sevilla, s.n.

- [S. A.]. Añasco, el de Talavera, S.l., s.n.

- [S. A.]. De Alcalá a Madrid, S.l., s.n.

- [S. A.]. El amor como ha de ser, S.l., s.n.

- [S. A.]. El bandolero de Flandes, Salamanca, Imprenta de la Santa Cruz.

- [S. A.]. El conde de Saldaña, primera parte, Barcelona, Juan Serra y Centené.

- [S. A.]. El ejemplo de desdichas y los casados por fuerza, S.l., s.n.

- [S. A.]. El mejor rey del mundo, y templo de Salomón, S.l., s.n.

- [S. A.]. El señor de noches buenas, S.l., s.n.

- [S. A.]. La corona del agravio, S.l., s.n. [microfilm, University of North Carolina at Chapel Hill].

CulL, J. T. [1996]. «'Hablan poco y dicen mucho': The Function of Discovery Scenes in the Drama of Tirso de Molina", The Modern Language Review, 91.3, 619-34.

- [2002], «Cuentan los naturales...': “Una imagen con resonancias emblemáticas en Don Quijote 1.33", in A. Bernat Vistarini and J. T. Cull (eds.), Los días del Alción: Emblemas, Literatura y Arte del Siglo de Oro, Barcelona, José J. de Olañeta, Universitat de les Illes Balears and College of the Holy Cross, 141-150.

- [2016]. "Some Stylistic Hall-marks in the Dramatic Works of Juan Ruiz de Alarcón», Bulletin of the Comediantes, 68.1, 39-64.

- [2017]. «El imaginario visual en la obra dramática de Álvaro Cubillo de Aragón», Criticón, 13, 93-120.

DaLY, P. M. [1979]. Literature in the Light of the Emblem, 2nd ed., Toronto, Toronto UP.

Grovio, Paolo. [1558]. Diálogo de las empresas militares y amorosas, Venecia, G. Giulito de Ferraris.

Godínez, F. [1773]. Amán, y Mardoqueo (por otro título, La horca para su dueño). Madrid, Antonio Sanz.

- [1991]. Aún de noche alumbra el sol, eds. P. Bolaños Donoso and P. M. Piñero Ramírez, Sevilla, Universidad, Kassel, Reichenberger.

- [S. A.]. Acertar de tres la una, S.l., s.n.

- [S. A.]. El primer condenado, S.l., s.n.

Horozco y Covarrubias, J. DE. [1589]. Emblemas morales, Segovia, Juan de la Cuesta.

Matos Fragoso, J. DE. [1653]. Estados mudan costumbres, in Quinta parte de comedias escogidas de los meiores ingenios de España ..., Madrid, Pablo de Val, pp. 80-127.

- [1654]. A su tiempo el desengaño, Madrid, Domingo Garcia y Morràs.

- [1665]. Los dos prodigios de Roma, in Parte veinte y tres de comedias nueuas, escritas por los mejores ingenios de España ..., Madrid, Ioseph Fernandez de Buendia, pp. 50-92.

- [1670]. El fénix de Alemania, vida y muerte de Santa Cristina, in Parte treinta y tres de Comedias nueuas, nunca impressas, escogidas de los mejores ingenios de España ..., Madrid, Ioseph Fernandez de Buendia, pp. 378-407.

- [1731]. Amor, lealtad y ventura, Madrid: Imprenta de Antonio Sanz.

- [1749]. El traidor contra su sangre, Madrid:,Imprenta de Antonio Sanz.

- [1751]. El genizaro de Hungría, Madrid, Imprenta de Antonio Sanz.

- [1756]. El hijo de la piedra, y segundo Pío Quinto, San Félix, Madrid, Imprenta de Antonio Sanz.

- [1765]. Ver y creer, Valencia, Imprenta de la Viuda de Joseph de Orga. 
Matos fragoso, J. De. [1772]. El delincuente sin culpa, y bastardo de Aragón, Imprenta de Joseph y Thomas de Orga.

- [1776]. Riesgos, y alivios de un manto, Valencia, Imprenta de Joseph y Thomás de Orga.

- [1828]. El yerro del entendido, in Comedias escogidas de Don Juan de Matos Fragoso, Tomo primero, Madrid, Imprenta de Ortega y Compañía.

- [1828]. Lorenzo me llamo, carbonero de Toledo, in Comedias escogidas de Don Juan de Matos Fragoso, Tomo primero, Madrid, Imprenta de Ortega y Compañía.

- [S. A.]. La venganza en el despeño, y tirano de Navarra, S.l., s.n.

- [S. A.]. Los bandos de Ravena y fundación de la Camándula, S.l., s.n.

- [S. A.]. Muchos indicios sin culpa, S.l., s.n.

Monroy y Silva, C. DE. [1745]. Las violencias del amor, Madrid: Antonio Sanz.

- [1768]. El robo de Elena, Valencia, Imprenta de la Viuda de Joseph de Orga.

- [1781]. Renegado, rey y mártir, Valencia, s.n.

- [S. A.]. El más valiente andaluz, Antón Bravo, Barcelona, Francisco Suriá y Burgada.

- [S. A.]. La alameda de Sevilla y recato en el amor, Sevilla, Francisco de Leefdael.

- [S. A.]. Lo que puede el desengaño y memoria de la muerte, s.l., s.n.

- [S. A.]. San Bartolomé en Armenia, s.l., s.n.

Moreto y Cabaña, A. De. [1650]. Lo que merece un soldado, in Parte quarenta y tres de comedias de diferentes autores, Zaragoça, Iuan de Ybar, pp. 1-36.

- [1659]. El más ilustre francés, San Bernardo, in Comedias nueuas escogidas de los mejores ingenios de España: onzena parte ..., Madrid, Gregorio Rodriguez, ff. 137v-159.

- [1661]. El Eneas de Dios, in Parte quinze, comedias nueuas, escogidas de los mejores ingenios de España ..., Madrid, Melchor Sanchez, ff. 154v-178r.

- [1670]. El azote de su patria, y renegado Abdenaga, in Parte treinta y quatro de Comedias nueuas escritas por los mejores ingenios de España ..., Madrid, Ioseph Fernandez de Buendia, pp. 421-46.

- [1671]. Empezar a ser amigos, in Parte treinta y cinco Comedias nueuas escritas por los mejores ingenios de España ..., Madrid, Lucas Antonio de Bedmar, pp. 348-386.

- [1673]. La discreta venganza, in Parte treinta y nueve de comedias nuevas de los mejores ingenios de España ..., Madrid, Ioseph Fernandez de Buendia, pp. 362v-404.

- [1753], La fingida Arcadia, Madrid: Antonio Sanz.

- [1856], El desdén con el desdén, in Luis Fernández-Guerra y Orbe (ed.), Comedias escogidas, Madrid: M. Rivadeneyra.

- [1856]. El defensor de su agravio, in Luis Fernández-Guerra y Orbe (ed.), Comedias escogidas, Madrid: M. Rivadeneyra.

- [1856]. El mejor amigo, el rey, in Luis Fernández-Guerra y Orbe (ed.), Comedias escogidas, Madrid: M. Rivadeneyra.

- [1856]. El secreto entre dos amigos, in Luis Fernández-Guerra y Orbe (ed.), Comedias escogidas, Madrid: M. Rivadeneyra.

- [1856]. El valiente justiciero, in Luis Fernández-Guerra y Orbe (ed.), Comedias escogidas, Madrid: M. Rivadeneyra.

- [1856]. En el mayor imposible nadie pierda la esperanza, in Luis Fernández-Guerra y Orbe (ed.), Comedias escogidas, Madrid: M. Rivadeneyra.

- [1856]. Industrias contra finezas, in Luis Fernández-Guerra y Orbe (ed.), Comedias escogidas, Madrid: M. Rivadeneyra.

- [1856]. La misma conciencia acusa, in Luis Fernández-Guerra y Orbe (ed.), Comedias escogidas, Madrid: M. Rivadeneyra. 
- [1856]. Lo que puede la aprehensión, in Luis Fernández-Guerra y Orbe (ed.), Comedias escogidas, Madrid: M. Rivadeneyra.

- [1856]. Los jueces de Castilla, in Luis Fernández-Guerra y Orbe (ed.), Comedias escogidas, Madrid: M. Rivadeneyra.

- [1856]. San Franco de Sena, in Luis Fernández-Guerra y Orbe (ed.), Comedias escogidas, Madrid: M. Rivadeneyra.

- [1856]. Trampa adelante, in Luis Fernández-Guerra y Orbe (ed.), Comedias escogidas, Madrid: M. Rivadeneyra.

- [S. A.]. El marqués del cigarral, Valladolid, Imprenta de Alonso del Riego.

- [S. A.]. El rosario perseguido, Sevilla, Joseph Antonio de Hermosilla.

Ortiz, L. [1677]. Memoria, entendimiento y voluntad. Empresas que enseñan y persuaden su buen uso en lo moral, y en lo político, Sevilla, Juan Francisco de Blas.

RIPA, C. [1603]. L'Iconologia, Roma, Lepido Facij.

SAAVEdRa FAJARDo, D. DE. [1642]. Idea de un príncipe político cristiano en cien empresas, Milan, S.n.

- [1999]. Empresas políticas, ed. Sagrario López Poza, Madrid, Cátedra.

Solís, A. DE. [1681]. Amparar al enemigo, in Comedias de don Antonio de Solís, Madrid, Melchor Álvarez.

- [1681]. Eurídice y Orfeo, in Comedias de don Antonio de Solís, Madrid, Melchor Álvarez.

- [1681]. Triunfos de amor, y fortvna, in Comedias de don Antonio de Solís. Madrid, Melchor Álvarez.

Sото, H. [1599]. Emblemas moralizadas, Madrid, Herederos de Juan Íñiguez Lequerica.

TÁrrega, F. [1609]. El cerco de Rodas, in Comedias de autores valencianos I, Barcelona, en casa Sebastian de Cormellas.

- [1609]. El prado de Valencia, Barcelona, en casa Sebastian de Cormellas.

- [1609]. La sangre leal de los montañeses de Navarra, Barcelona, Sebastián de Cormellas.

TÁRREGA, F. [1609]. Las suertes trocadas, y torneo venturoso, in Comedias de autores valencianos I, Barcelona, Sebastian de Cormellas.

- [1616]. La duquesa constante, Valencia, Felipe Mey.

- [1616]. La enemiga favorable, in Flor de las comedias de España de diferentes autores: quinta parte, Barcelona, en casa Sebastian de Cormellas, ff. 307r-334v.

- [1616]. La fundación de la orden de Nuestra Señora de la Merced por el Rey Don Jaime, in Norte de la poesia española: illustrado del sol de Doze comedias (que forman segunda parte) de laureados poetas valencianos, $y$ de doze escogidas loas y otras rimas a varios sugetos, Valencia, Felipe Mey.

VillaizÁn y Garcés, J. De. [1636]. Ofender con las finezas, in Parte treynta de comedias famosas de varios autores, Zaragoza, el Hospital Real y General de Nuestra Señora de Gracia.

- [1636]. Venga lo que viniere, in Parte veinte y nueve : contiene doze comedias famosas de varios autores, Valencia, Siluestre Esparsa, ff.99r-116r.

- [1653]. A gran daño gran remedio, in Doze comedias las mas grandiosas que hasta aora han salido, de los mejores, y más insignes poetas, Lisboa, Pablo Craesbeeck, pp. 223-269.

- [S. A.]. Transformaciones de amor, Sevilla, Francisco de Leefdael.

Villava, J. F. DE. [1613]. Empresas espirituales y morales, Baeza, F. Díaz de Montoya.

ZABALETA, J. DE. [1659 = 1885]. El día de fiesta por la mañana y por la tarde, ed. A. R. Chaves, Madrid, Diego Pacheco y Latorre. 


\section{APPENDIX: ESSENTIAL STUDIES ON EMBLEMATICS AND SPANISH GOLDEN AGE THEATER}

Alonso Rey, M. D. [2008], «Iconografía cristiana y emblemas escénicos en los autos sacramentales de Calderón de la Barca», in C. Chaparro Gómez, J. J. García Arranz and J. Ureña Bracero (eds.), Paisajes emblemáticos: La construcción de la imagen simbólica en Europa y América, Mérida, Editora Regional de Extremadura, 269-280.

Ambrose, T. [2004], «Lope de Vega and Titian: The Goddess as Emblem of Sacred and Profane Love", in F. A. de Armas (ed.), Writing for the Eyes in the Spanish Golden Age, Lewisburg, Bucknell UP, 167-184.

Arellano, I. [1990]. "Piedras y pájaros: Ilustración extravagante a un pasaje del Médico de su honra de Calderón", Bulletin Hispanique (Hommage à Maxime Chevalier), 92.1, 59-69.

Armas, F. A. DE. [1995]. «Los Emblemas morales de Sebastián de Covarrubias y las comedias de Lope de Vega", in Estudios de Arte. Homenaje al profesor Martín González, Valladolid, Secretariado de Publicaciones de la Universidad de Valladolid, 209-305.

Bouzy, C. [1999], "Calderón et l'emblématique», in N. Ly (ed.), Aspects du théâtre de Calderón. La vida es sueño. El gran teatro del mundo. Pedro Calderón de la Barca, París, Editions du Temps, 13-40.

Brito Díaz, C. [1996], «〈Odore enecat suo’: Lope de Vega y los emblemas», in S. López Poza (ed.), Literatura Emblemática Hispánica. Actas del I Simposio Internacional, septiembre de 1994, La Coruña, Universidade da Coruña, 355-378.

Cardona Castro, A. [1996], "Estudio de los emblemas en los Autos Sacramentales de Calderón: El veneno y la triaca y La cura y la enfermedad», in S. López Poza (ed.), Literatura Emblemática Hispánica. Actas del I Simposio Internacional, septiembre de 1994, La Coruña, Universidade da Coruña, 401-414.

Castro Jiménez, M. D.n[2011], "Amor filiorum: el ejemplo del pelícano», in B. Antón Martínez and $\mathrm{M}^{\mathrm{a}} \mathrm{J}$. Muñoz Jiménez (eds.), Estudios sobre florilegios y emblemas. "Manet semper virtus odosque rosae». Homenaje a la memoria de la Profesora Ana María Aldama Roy, Valladolid, Universidad de Valladolid, 109-118.

Cull, J. T. [1992]. "Emblematics in Calderón`s El médico de su honra», Bulletin of the Comediantes, 44.1, 113-31.

— [1993]. "Calderón's Snakes: Emblems, Lore and Imagery», MIFLC Review, 3, 97-1 10.

- [1994]. «Emblems in the Secular Drama of Calderón: A Review Article», Romance Quarterly, 41.2, 79-91.

- [1996a]. "'Hablan poco y dicen mucho': The Function of Discovery Scenes in the Drama of Tirso de Molina", The Modern Language Review, 91.3, 619-34.

- [1996b], "Emblematic Representation in the autos sacramentales of Calderón", in M. Delgado (ed.), The Calderonian Stage: Body and Soul, Lewisburg, PA, Bucknell UP, 107-32.

- [2000a], "El teatro emblemático de Mira de Amescua», in R. Zafra and J. J. Azanza (eds.), Emblemata Aurea. La Emblemática en el Arte y la Literatura del Siglo de Oro, Madrid, Akal, 127-142.

- [2000b], "La presencia de la emblemática en algunas comedias del Siglo de Oro», in V. Mínguez (ed.), Del libro de emblemas a la ciudad simbólica. Actas del III Simposio Internacional de Emblemática Hispánica, 2 vols., Castelló de la Plana, Publicacions de la Universitat Jaume I, II, 587-602. 
- [2002], «Ecos emblemáticos en la obra dramática de Ruiz de Alarcón», in H. Pérez Martínez and B. Skinfill (eds.), Esplendor y ocaso de la cultura simbólica, Mexico, El Colegio de Michoacán, 47-55.

- [2016]. "Some Stylistic Hall-marks in the Dramatic Works of Juan Ruiz de Alarcón», Bulletin of the Comediantes, 68.1, 39-64.

- [2017a]. «El imaginario visual en la obra dramática de Álvaro Cubillo de Aragón», Criticón, 130, 93-120.

- [2017b]. "Mi vida anda de un hilo pendiente. Precarity and Power in the Dramatic Works of Juan Pérez de Montalbán», Bulletin Hispanique, 119.1, 101-116.

- [Forthcoming]. «A mí no hable en emblemas. The Function of Emblematics in the Plays of Juan Pérez de Montalbán», Forthcoming in Revista de Estudios Hispánicos.

DANKER, F. E. [1972]. «Emblematic Technique in the Auto Sacramental: Calderón's No hay más Fortuna que Dios", Comparative Drama, 6.1, 40-50.

Defris de Calvo, EMILIA I. [1986]. "Amor y emblemas en la historia de Everardo de El peregrino en su patria, de Lope de Vega", Letras: Organo de la Facultad de Letras y Ciencias Humanas de la Universidad Nacional Mayor de San Marcos 17-18, 11-17.

Dixon, V. [1981]. «Beatus... Nemo: El villano en su rincón, las 'polianteas' y la literatura de emblemas", Cuadernos de Filología III: Literaturas, Análisis, 1-2, 279-300.

- [1986]. «La comedia de corral de Lope como género visual», Edad de Oro, 5, 35-58.

- [1992]. "The Emblemas morales of Sebastián de Covarrubias and the Plays of Lope de Vega", Emblematica 6.1, 83-101.

Dodman, M. J. [2004]. «La linda bestia y la hermosa discreta: hacia una interpretación simbólica y emblemática de La dama boba», Revista Canadiense de Estudios Hispánicos 29. $1,99-110$.

EGIDo, A. [1991], «El telón como jeroglífico de 'La fiera, el rayo y la piedra' (1690)», in M. V. Diago and T, Ferrer (eds.), Comedias y comediantes. Estudios sobre el teatro clásico español (mayo de 1989), Valencia, Universidad de Valencia, 387-405.

Golden, B. [1970]. «Calderón's Tragedies of Honor: Topoi, Emblem, and Action in the Popular Theater", Renaissance Drama, 3, 239-62.

Halkoree, P. R. K. [1972-73]. «Lope de Vegaıs El villano en su rincón: An emblematic Play», Romance Notes 14, 141-145.

HiLLACH, ANSGAR. [1978], «Sakramentale Emblematik bei Calderón», in Sibylle Penkert (ed.), Emblem und Emblematikrezeption. Vergleichende Studien zur Wirkungsgechichte von 16 bis 20 Jahrundert, Darmstadt, Wissenchaftliche Buchgesellschaft, 194-20.

InFANTES De MigueL, V. [1983], "Calderón y la literatura jeroglífica», in Actas del "Congreso Internacional sobre Calderón y el teatro español del siglo de Oro" (Madrid, 1981), Madrid, Anejos de la Revista Segismundo, 1593-1602.

Martins, H. [1969]. «La Estrella de Sevilla como emblema», Barroco 1, 75-79.

MARISCAL, GEORGE. [1981]. «Iconografía y técnica emblemática en Calderón: La devoción de la cruz», Revista Canadiense de Estudios Hispánicos, 5.3, 339-354.

Mccready, W. T. [1957]. "Empresas, in Lope de Vega's works», Hispanic Review 25.2, 79-104.

MorR, D. W. [1971], "Lope de Vega's Fuenteovejuna and the Emblemas morales of Sebastián de Covarrubias Horozco (with a few remarks on El villano en su rincón)", in A. D. Kossoff and J. Amor y Vázquez (eds.), Homenaje a William L. Fichter, Madrid, Castalia, 537-546.

Oppenheimer, M. [1952]. "Two Stones and One Bird: A Bird Lore Allusion in Calderón», Modern Language Notes, 67, 253-4. 
Restrepo-Gautier, P. [2001]. La imaginación emblemática en el drama de Tirso de Molina. Newark, Del., Juan de la Cuesta.

Rodríguez De LA Flor, F. [1985]. «Dos jeroglíficos calderonianos para una arquitectura efímera en la Salmanca del Seiscientos», Salamanca: Revista de Estudios, 15. 115-126.

Roso Díaz, J. [2008], «La imagen del héroe en el teatro barroco español. García de Paredes y la construcción de un emblema», in R. García Mahíques and V. F. Zuriaga Senent (eds.), Imagen y Cultura. La Interpretación de las Imágenes como Historia Cultural, Valencia, Generalitat Valenciana, 1413-1424.

Sмітн, D. L. "Tirso's Use of Emblems as a Technique of Representation in La mujer que manda en casa», Bulletin of the Comediantes 37, 71-81.

Soons, A. C. [1971]. "Calderon Dramatizes an Emblem: No hay cosa como callar», Arcadia, 6, 72-74.

- [1962]. "The emblematic technique in Las Paces de los Reyes», The Theater Annual, 19, 43-45.

Trambaioli, M. [1997], "Las empresas dramáticas calderonianas de tema mitológico sobre la educación del perfecto príncipe cristiano", in S. Kazimierz (ed.), Actes du Congrès International Théâtre, Musique et Arts dans le Cours Européenes de la Renaissance et du Baroque, Varsovie, 23-28 septembre 1996, Varsovia, Éditions de l' Université de Varsovie, 269-86.

Triwedi, M. D. [1977]. "The Source and Meaning of the Pelican Fable in El castigo sin venganza», Modern Language Notes, 92, 326-329.

Valbuena Briones, A. [1983], "El emblema 'in temerarios' en Calderón», in A. González, A. Rodríguez and T. Holzapfel (eds.), Estudios sobre el Siglo de Oro en Homenaje a Raymond R. MacCurdy, Madrid, 193-204.

- [1985]. "La concepción emblemática en la representación del teatro calderoniano», RILCE, 1, 285-295.

Vosters, S. A. [1977], "La literatura emblemática y epigráfica», in Lope de Vega y la tradición occidental, Madrid, Castalia, 1977, Parte II, El manierismo de Lope de Vega y la literatura francesa, 33-62.

Walthaus, R. [2001], “'Femme forte’ y emblema dramático: La Jezabel de Tirso y la Semíramis de Calderón», in C. Strosetzki (ed.), Actas del V Congreso de la Asociación Internacional Siglo de Oro, Madrid, Iberoamericana Vervuert, 1341-1349. 